\title{
Radio-telemetry techniques in the study of displacement of freshwater anomurans
}

Luciane Ayres-Peres, Cadidja Coutinho, Joele S. Baumart, Alberto S. Gonçalves, Paula B. Araujo and Sandro Santos

(LAP, PBA) PPG em Biologia Animal, Laboratório de Carcinologia, Instituto de Biociências/ Departamento de Zoologia, Universidade Federal do Rio Grande do Sul. Avenida Bento Gonçalves, 9500. Prédio 43435. Bairro Agronomia. CEP - 91501-970. Porto Alegre, RS, Brazil. Email: (LAP) lucianeayres@hotmail.com; (PBA) pbaraujo@portoweb.com.br

(CC, JSB, ASG, SS) PPG em Biodiversidade Animal, Laboratório de Carcinologia, Departamento de Biologia, Universidade Federal de Santa Maria. Avenida Roraima, 1000. Bairro Camobi. CEP 97105-900. Santa Maria, RS, Brazil. E-mail: (SS) ssantos@smail.ufsm.br

\section{Abstract}

In an ecological context, information on the movement and activity is important for understanding the requirements of habitat, resource usage patterns and the potential of interspecific interactions. The aim of this study was to examine the displacement pattern on daily activity and occupancy of substrates by Aegla manuinflata using radio-telemetry technique on field on Southern Brazil. Four adult males were monitored during nine days. The aeglids showed a significantly greater displacement toward upstream than downstream. Aegla manuinflata individuals showed higher displacement activity during the night period. Although activity was not constant: the animals spent one or more days without displacement. All aeglids showed locomotion activity concentrated between 11:43 p.m. and 02:25 a.m., although it was not restrict to sunset period and night. Individuals showed specific occupation of different types of substrate, but a pattern in the occupation of substrates as a function of the photoperiod was not observed. In this study, using a new technique for tracking aeglids, it was concluded that $A$. manuinflata is capable of actively dislocate throughout the stream, either toward upstream and downstream, passing through obstacles which may represent ability of re-colonization. The animals are more active during the night period, probably a strategy to avoid predators that are active during the day; the selection of substrate is not associated to sediment texture.

Key words: Aeglidae, Circadian rhythm, Substrate preference.

\section{Introduction}

Information on the movements and activity of animals is important for understanding their requirements of habitat, resource usage patterns and the potential of interspecific interactions (Sutherland, 1996). The movements of animals are connected both to the acquisition of primary resources (for instance, food, shelter and partners for mating) and also to avoidance of stress sources 
(predators, thermal extremes and dehydration) (Barbaresi et al., 1997). The movement patterns of individuals and populations may reflect ecological and growth responses to environmental heterogeneity (Southwood, 1977; Levine et al., 1984; Cohen and Levin, 1991).

Movement is a fundamental, yet relatively poorly understood population process. Although population ecology has traditionally concentrated on understanding temporal fluctuations in abundance (Turchin, 1998), more recently the focus has shifted to spatially explicit approaches, leading to a greater appreciation of the importance of movement (Steinberg and Kareiva, 1997). Moreover, it has been acknowledged that some important population phenomena depend not only on spatial changes in average population density, but also on individual movement behaviour (Morales and Ellner, 2002; Kokko and LópezSepulcre, 2006). Interactions between life history, physiology, behaviour and habitat make individual movement an exceptionally complex phenomenon (Patterson et al., 2008).

A number of studies have been conducted in crustaceans using different telemetry techniques, in order to provide information on home range, migration patterns and activity of these animals (Palinura: Smith et al., 1998; Watson III et al., 1999; Astacidea: Bubb et al., 2002; Anomura: González-Gurriarán et al., 2002; Jørgensen et al., 2007; Brachyura: Clark et al., 1999; Turner et al., 2003; Guerra-Castro et al., 2007; Lynch and Rochette, 2007). Stand out the studies using radio-telemetry techniques, such as those conducted by Robinson et al. (2000), who examined the movement patterns and the living area of Austropotamobius pallipes (Lereboullet, 1858), by Bubb et al. (2002a), who evaluated the movements and activities of Pacifastacus leniusculus (Dana, 1852) and by Bubb et al. (2004), who studied the movement and dispersion of $P$. leniusculus.

Crustaceans show some advantages as potential targets of telemetry, such as the existence of an exoskeleton, which represents a solid and relatively inert surface to which transmitters and a series of sensors may be fixed. In aquatic environments, where most crustaceans live, the capacity of direct observation in nature is limited by water clarity, substratum structural complexity and diving propensity (Wolcott, 1995). Another advantage of telemetry is that a number of individuals can be monitored at the same time by using an individual marker for each organism. This differs from traditional tagging and recapturing techniques, in which individuals are tagged only at specific places and, generally, not very frequently during their lives, such that long-range movements are difficult to detect for many animals (Hedin and Ranius, 2002).

Many decapod crustaceans synchronize certain behaviors with daily light/ dark cycles. Both laboratory and field data suggest that these rhythms are controlled by circadian clocks that are strongly influenced by environmental factors, particularly by light (Aréchiga and Atkinson, 1975; Karnofsky et al., 1989; Aréchiga et al., 1993; Palmer, 1995; Aréchiga and Rodríguez-Sosa, 1997; Skajaa et al., 1998; Jury et al., 2005). However, although laboratory studies are useful to identify trends in a species with respect to being active in a determined time of the day or night, or for determining whether this pattern is triggered by an endogenous clock, the real activity pattern expressed by an animal in its natural habitat is often influenced by additional factors (Golet et al., 2006). It is well known that exposure to light may affect a number of physiological processes in crustaceans, such as locomotion, food, mating, changes in color and metabolism (Meyer-Rochow, 1994).

The micro- and medium-scale movements of aeglids, the only continental water anomuran, are not very well known (Lopez, 1965). The Aeglidae family is restricted to the South American Neotropical region, occurring in streams, flooding rivers and lakes. These animals play a fundamental role in the food chain of limnetic systems (Arenas, 1976; Santos et al., 2008; Cassini et al., 2009). With the aid of radio-telemetry, it is possible to accurately follow the movements of these 
animals in time and space, thus providing unprecedented information on aeglids biology and behavior in their natural environment.

Sixty nine species are known for the Aeglidae (McLaughlin et al., 2010), some of which are highly threatened by environmental degradation (Pérez-Losada et al., 2002; BondBuckup et al., 2003), and in Brazil, twelve of these species are considered threatened according to IUCN criteria (Critically Endangered, Endangered and Vulnerable) (Magris et al., 2010). Information about movement patterns of aeglids can be relevant to analyze the impacts on these animals and also to understand the possible strategies of species that inhabit threatened environments.

Radio-telemetry was used in the present study to answer the following questions about Aegla manuinflata Bond-Bukup and Santos, 2009 in their natural environment in southern Brazil: 1) what are the displacement patterns of this species; 2) what are their activity rhythms in their natural environment; and 3) how does their occupation of different substrates occur?

\section{Material and Methods}

Study area: Our experiment was conducted in the Passo da Taquara Stream (29036'01'S - 5410'37'W, 158 m altitude) (Fig. 1), state of Rio Grande do Sul, Brazil. This stream is characterized by a temperature range of 16.8 to $24.1^{\circ} \mathrm{C}$ and a flow range of 0.01 to $0.07 \mathrm{~m}^{3} / \mathrm{s}$ throughout the year.

The bottom of Passo da Taquara Stream is composed of five kinds of substrate according to sedimentary scale of Wentworth: boulders $(\varnothing=256-\infty \mathrm{mm})$, cobble $(\varnothing=64-256 \mathrm{~mm})$, pebble $(\varnothing=4-64 \mathrm{~mm})$, granule $(\varnothing=2-4$ $\mathrm{mm})$ and sand $(\varnothing<2.0)$, with a predominance of boulders and their subdivisions. The bottom of the river was previously mapped for kind substrate through the use of sieves. The stream banks exhibit variations in the ground cover by vegetation from absent to scattered or dense; in the last case, the streambed is covered with its branches. This vegetation supplies the watercourse with organic matter, that is mainly present in the deeper stretches of the stream because of the slower speed of floodwater in these sites.

Capturing and tagging: Traps, baited with bovine liver, were used for capturing aeglids. The transmitters were attached with nontoxic glue (adhesive cyanoacrylate) to four adult males in the intermolt stage (Tab. 1). The low number of tagged animals is justified by the small size of the stream, sectioned into three branches, each of which is approximately $80 \mathrm{~m}$. Besides, a similar number of animals has been used satisfactorily in other studies with crustaceans in large areas, such as estuaries, the open sea and even in large rivers (Clark et al., 1999, with Callinectes sapidus Rathbun, 1896 $\mathrm{n}=5$; Gherardi et al., 2000, with Procambarus clarkii (Girard, 1852) $-\mathrm{n}=5$, Carr et al., 2004, with C. sapidus - n = 8; Jørgensen et al., 2007, with Paralithodes camtschaticus (Tilesius, 1815) - n = 7; Lynch and Rochette, 2007, with Carcinus maenas (Linnaeus, 1758) $-\mathrm{n}=6$ ).

All captured aeglids were measured and weighed but only four individual of the appropriate size and weight to bear the transmitters were selected (Tab. 1). In a previous analysis conducted in a laboratory and in the natural habitat, in ad libitum observations it was verified that the experimental individuals behaved in the same way as non-tagged individuals. In addition, they were able to hide under rocks in the same manner as non-tagged animals. Therefore it was concluded that the transmitters did not significantly affect the behavior of tagged individuals. It is largely known that transmitters (tags) weighing up to $10 \%$ of the of specimens body mass do not interfere in its activity, behavior and/or survival (Clark et al., 1999; Robinson et al., 2000; Bubb et al., 2002a and 2004; GuerraCastro et al., 2007). In this study, transmitters weighing between 0.3 and $0.4 \mathrm{~g}$ were used, which are less than $10 \%$ of the body weight of studied aeglids.

Monitoring: The surface of aeglids was dried, and the transmitters were glued to 


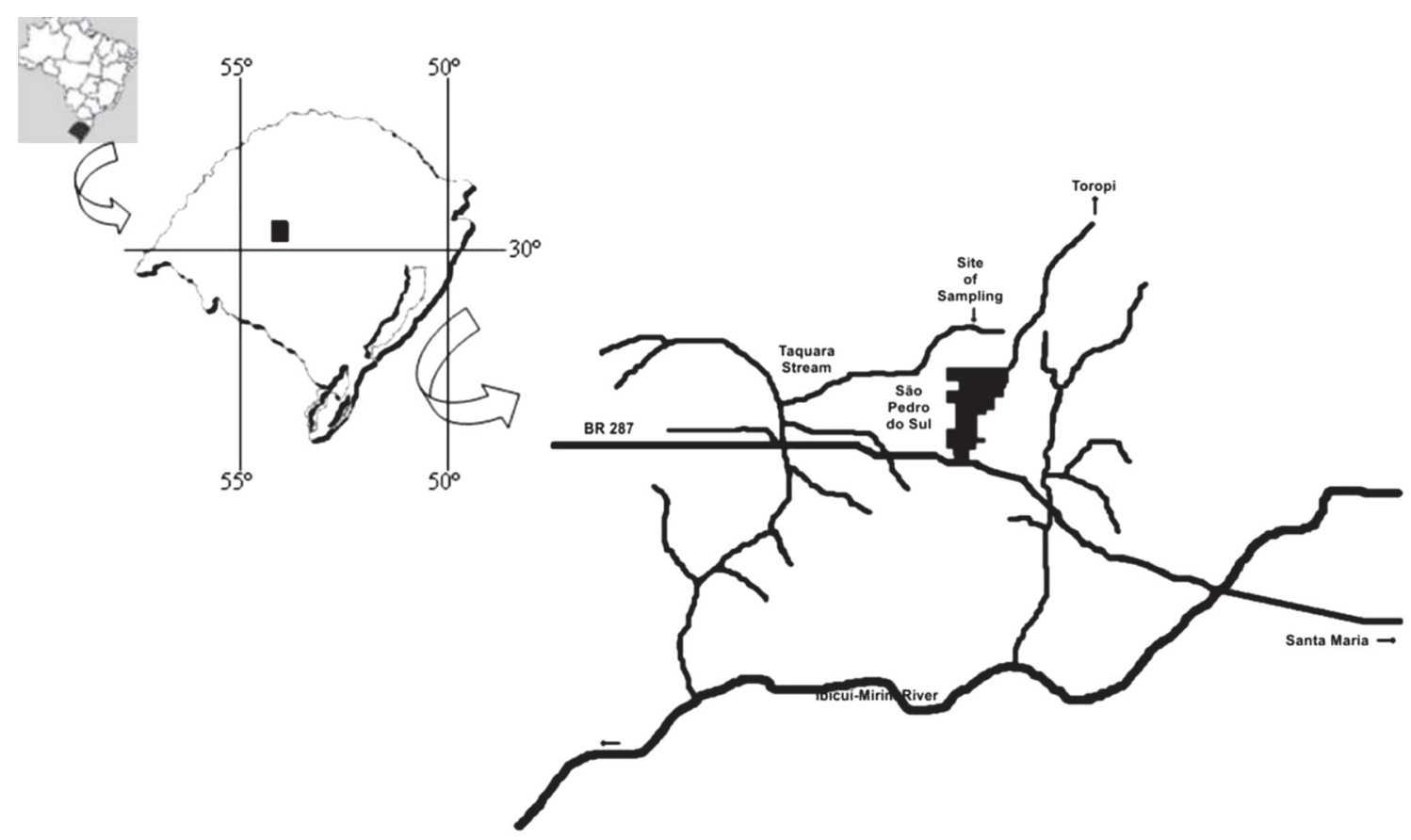

Figure 1. Schematic representation of localization of Passo da Taquara Stream on Southern Brazil.

the cephalothorax (Fig. 2). The transmitters used (model BD-2N) have a lifespan of approximately 12 days within a range of 50 to 100 meters in the frequencies shown in Tab. 1. The transmitters were acquired from Holohil Systems Ltd. The signals were received by a receptor (model TRX-16S) equipped with a Yagi three element antenna from Wildlife Material International, Inc.

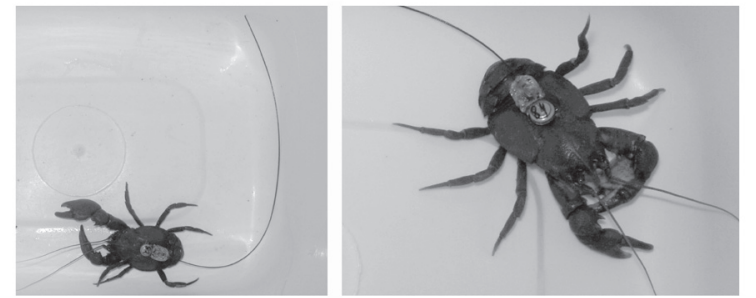

Figure 2. Aegla manuinflata. Aeglid with transmitter attached on its cephalothorax.

Tagged animals were monitored for a period of approximately nine days (the lifespan of tags in the field) with radio sightings conducted every three hours to obtain an estimate of day and night movements. After their release, the aeglids were observed to determine their movements downstream or upstream from the point of release, in addition to the record of their displacement area during that period of time.

\section{Data analysis}

Displacement: For each specimen, the day and night displacement was calculated, i.e., the displacement was quantified in meters between each monitoring time $(3,6,9$ and 12 a.m., and 3, 6, 9 and 12 p.m.). Before the displacement analysis, the data normality was checked by the Shapiro-Wilk test, as they were non-parametric ( $\mathrm{p}<0.0005)$, the KruskalWallis test ( $\mathrm{H}$ test) was used to compare the displacement rate among the four individuals, and the $G$ test was used to compare the displacement rate between day and night. The statistical tests were conducted using Past 1.95 software (Hammer et al., 2001).

Circadian activity: To determine whether the aeglids exhibited different activity patterns during the circadian cycle, a circular statistic was employed, which analyzes the distribution of displacement (in $\mathrm{m}$ ) during the day. To determine their activity, the sum of the displacement of the animals at each sighting times was used (3, 6, 9 and 12 a.m., and 3, 6, 9 and 12 p.m.) over seven experimental days (from the $2^{\text {nd }}$ to the $8^{\text {th }}$ day; the $1^{\text {st }}$ and $9^{\text {th }}$ days were excluded from this analysis because on 
the $1^{\text {st }}$ day, monitoring was performed after 12 p.m., and on the $9^{\text {th }}$ day, a complete set of data was not available for all animals due to the loss of the signal from the transmitters). The activity levels were tested for a non-random distribution using a Rayleigh Z-Test, which was conducted using Oriana software (Kovach, 1994). To compare the activity patterns among the four individuals, a $\chi^{2}$ test was applied.

Space occupation: The relationship between the kinds of substrate occupied by the four individuals of $A$. manuinflata and their distribution was determined by the Mantel Test (Manly, 2000). For this purpose, the data were standardized by the arcsin function (because data were presented as \%), and the Euclidian distance was used to evaluate similarity.

The Mantel test is a non-parametric procedure based on randomization that generates statistics at significant levels for a correlation between matrix distances without supposing specific probability distributions (Cesaroni et al., 1997). This test utilizes permutation, and the association between these two matrices can be tested by the $\mathrm{Z}$ distribution, such that it can establish the statistical significance of the matrix correlation (Sokal, 1979; Smouse et al., 1986; Manly, 1990; Cesaroni et al., 1997). Normalization was conducted to transform $\mathrm{Z}$ into a coefficient (r), which varies from -1 to +1 . The significance of $Z$ was determined using a Monte Carlo permutation test (Smouse et al., 1986) with 5,000 permutations. The Mantel test was conducted in the statistical program NTSYS 2.I (Rohlf, 2000).

For the Mantel test, two matrices were built based on two hypotheses to be compared to the similarity matrix of the substrate composition (sand, cobble, granule, slab, boulder and gravel):

1. Similarity matrix 1 (SM1): considering the structuring related to the four individuals, i.e., the evaluation of whether the usage of different substrates reflects individual preferences.

2. Similarity matrix 2 (SM2): considering whether there is structuring by photoperiod (day/night) depending on the occupied substrates.

In addition to the hypothesis tests, the kind of substrate preferentially occupied by the four individuals was evaluated.

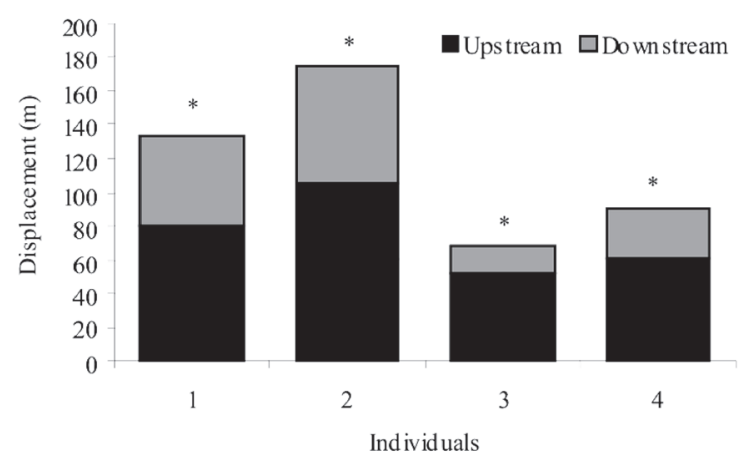

Figure 3. Aegla manuinflata, animals monitored by radio-telemetry at a stream on Southern Brazil on February/2009: displacement of four individuals $(1,2,3$ and 4) downstream and upstream during eight days of observation. $\left.{ }^{*}\right)$ Represents significant difference using $\chi^{2}$ test $(\mathrm{p}<0.0001)$.

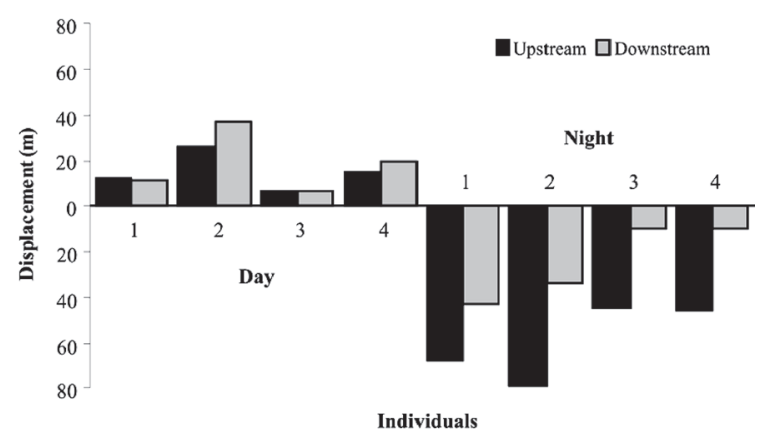

Figure 4. Aegla manuinflata. Animals monitored by radio-telemetry at a stream on Southern Brazil on February/2009: displacement of four individuals (1, 2, 3 and 4) downstream and upstream during eight days of observation considering displacement on day time $(9$ a.m., 12 a.m., 3 p.m. and 6 p.m.) and night time (12 p.m., 3 a.m., 6 a.m. and 9 p.m.).

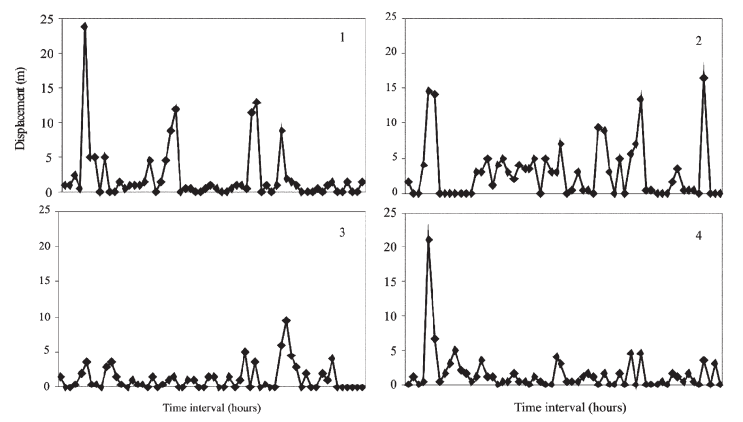

Figure 5. Aegla manuinflata. Daily locomotion activity (at each three hours) of four individuals. Animals monitored by radio-telemetry at a stream on Southern Brazil on February/2009. 
Table 1. Aegla manuinflata. Data of animals used on radio-telemetry experiment on Southern Brazil on February/2009. CL = Cephalothorax Length; RPL = Right Propod Lenght; LPL = Left Propod Length; PH = Propod Height; W = Weight of animal and TF = Transmitter Frequency.

\begin{tabular}{ccccccc}
\hline Individual & $\mathrm{CL}(\mathrm{mm})$ & $\mathrm{RPL}(\mathrm{mm})$ & $\mathrm{LPL}(\mathrm{mm})$ & $\mathrm{PH}(\mathrm{mm})$ & $\mathrm{W}(\mathrm{g})$ & $\mathrm{TF}(\mathrm{MHz})$ \\
\hline 1 & 18.64 & 15.02 & 17.71 & 11.06 & 4.72 & 150.019 \\
2 & 19.02 & 16.94 & 13.18 & 11.17 & 4.72 & 150.037 \\
3 & 19.23 & 14.21 & 16.48 & 11.10 & 4.77 & 150.057 \\
4 & 18.64 & 14.31 & 16.51 & 10.52 & 4.64 & 150.097 \\
\hline
\end{tabular}

Table 2. Aegla manuinflata. Displacement of four individuals (1,2, 3 and 4) monitored by radio-telemetry at a stream on Southern Brazil on February/2009.

\begin{tabular}{ccccccc}
\hline & \multicolumn{3}{c}{ Displacement $(\mathrm{m})$} \\
\hline $\begin{array}{c}\text { Minimum } \\
(3 \mathrm{~h})\end{array}$ & $\begin{array}{c}\text { Maximum } \\
(3 \mathrm{~h})\end{array}$ & $\begin{array}{c}\text { Minimum } \\
(24 \mathrm{~h})\end{array}$ & $\begin{array}{c}\text { Maximum } \\
(24 \mathrm{~h})\end{array}$ & $\begin{array}{c}\text { Mean } \pm \text { sd } \\
(8 \text { days })\end{array}$ & $\begin{array}{c}\text { Total } \\
(8 \text { days })\end{array}$ \\
\hline 1 & 0 & 24 & 4.5 & 40.5 & $2.48 \pm 4.39$ & 134 \\
2 & 0 & 16.5 & 5.5 & 39 & $3.24 \pm 4.08$ & 175 \\
3 & 0 & 9.5 & 2.0 & 21 & $1.33 \pm 1.86$ & 69 \\
4 & 0 & 21 & 1.5 & 41 & $1.67 \pm 3.09$ & 90.5 \\
\hline Mean & 0 & 17.75 & 3.37 & 35.37 & - & 117.87 \\
\hline
\end{tabular}

Table 3. Aegla manuinflata Animals monitored by radio-telemetry at a stream on Southern Brazil on February/2009: total sum in meters of displacements of four individuals, and in parenthesis the percentage (\%) downstream and upstream during eight days of observation.

\begin{tabular}{lccccccccc}
\hline $\begin{array}{l}\text { Displacement } \\
(\mathrm{m})\end{array}$ & Day 1 & Day 2 & Day 3 & Day 4 & Day 5 & Day 6 & Day 7 & Day 8 & Total \\
\hline Total & 6.5 & 14.5 & 20 & 45 & 11.5 & 23 & 20.5 & 31 & 172 \\
downstream & $(46.4)$ & $(11.9)$ & $(42.6)$ & $(73.2)$ & $(31.5)$ & $(23.6)$ & $(38.7)$ & $(82.7)$ & $(36.7)$ \\
Total & 7.5 & 107 & 27 & 16.5 & 25 & 74.5 & 32.5 & 6.5 & 296.5 \\
upstream & $(53.6)$ & $(88.1)$ & $(57.4)$ & $(26.8)$ & $(68.5)$ & $(76.4)$ & $(61.3)$ & $(17.3)$ & $(63.3)$ \\
$\begin{array}{l}\text { Total } \\
\text { displacement }\end{array}$ & 14 & 121.5 & 47 & 61.5 & 36.5 & 97.5 & 53.05 & 37.5 & 468.5 \\
\hline
\end{tabular}

Table 4. Aegla manuinflata. Circular statistical results indicating periods of higher circadian activity of four individuals. Animals monitored by radiotelemetry at a stream on Southern Brazil on February/2009. $\left(^{*}\right)$ Represents significant difference using Rayleigh's Test.

\begin{tabular}{ccccc}
\hline & Indiv. 1 & Indiv. 2 & Indiv. 3 & Indiv. 4 \\
\hline Mean Vector $(\mu)$ & $02: 25$ a.m. & $00: 55$ a.m. & $00: 35$ a.m. & $11: 43$ p.m. \\
Length of Mean Vector $(r)$ & 0.366 & 0.202 & 0.238 & 0.221 \\
Rayleigh Test $(\mathrm{Z})$ & 21.116 & 8.076 & 5.838 & 5.776 \\
Rayleigh Test $(\mathrm{p})$ & $6.75 \mathrm{E}-10^{*}$ & $3.11 \mathrm{E}-4^{*}$ & $0.003^{*}$ & $0.003^{*}$ \\
\hline
\end{tabular}

\section{Results}

\section{Displacement}

Among the monitored animals, the highest displacement was performed by individual $\mathrm{n}^{\circ} 2$ that displaced $175 \mathrm{~m}$ during the eight days of monitoring (Tab. 2). Only individuals 2 and 3 showed significant differences related to the displacement rate $(\mathrm{H}$ $=5.813 ; \mathrm{p}=0.02$ ).

Regarding downstream and upstream movement (Tab. 3), the animals exhibited a significantly displacement upstream $\left(\chi^{2}=\right.$
768.3; $\mathrm{p}<0.0001$ ), which was also observed when the four individuals were analyzed separately (Fig. 3). The night period was characterized by larger displacement than that daytime period (downstream and upstream) $(\mathrm{G}$ test $=153.79 ; \mathrm{p}<0.0001$ for the four analyzed individuals together) (Fig. 4). It became evident that aeglids were capable to overcome natural barriers because at least one individual (individual $\mathrm{n}^{\circ} 2$ ) traversed three small waterfalls $(60,70$ and $80 \mathrm{~cm}$ high) that exhibited high-speed flows.

The displacement of aeglids was not constant since each animal spent one or more 

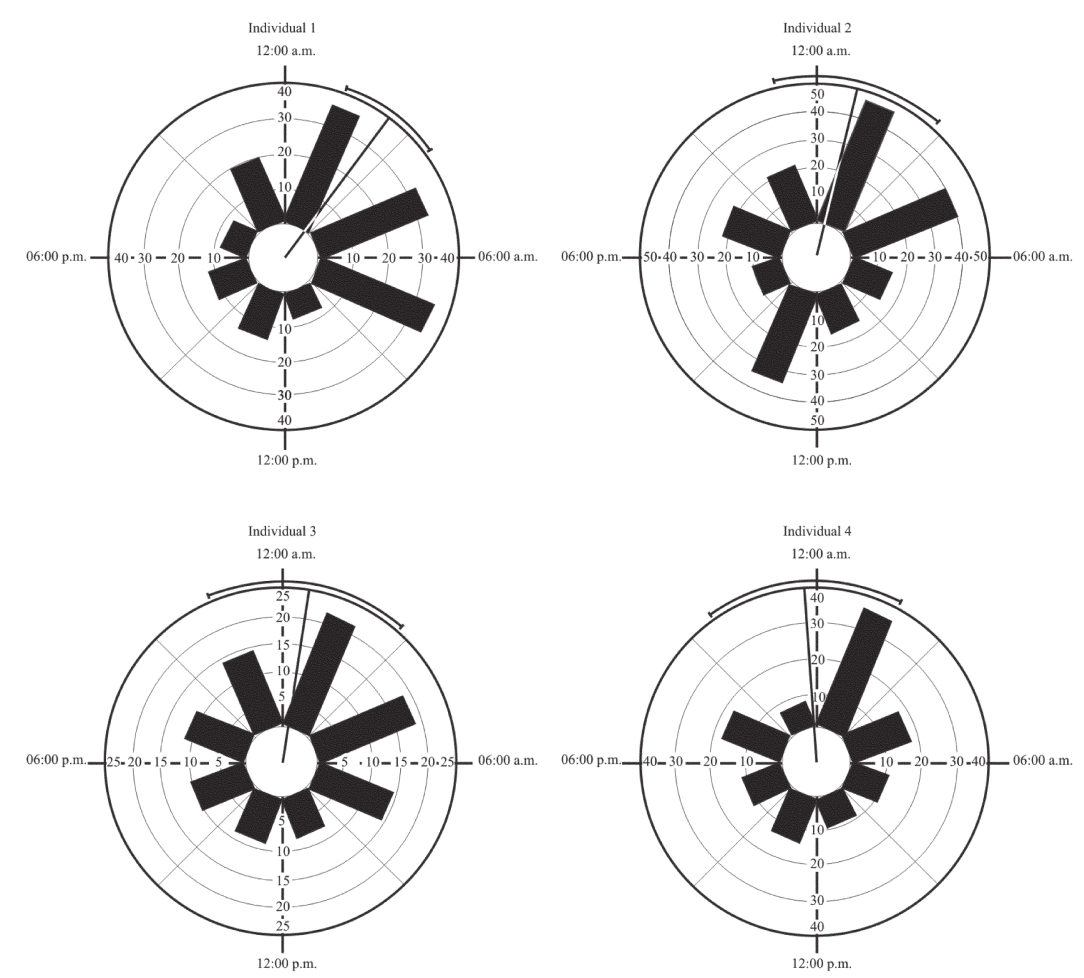

Figure 6. Aegla manuinflata. Circadian activity of four individuals during seven days of observation (at each three hours). Bars represent the total sum of displacement (in meters) and vectors indicate the average and confidence intervals (95\%). Animals monitored by radio-telemetry at a stream on Southern Brazil on February/2009.

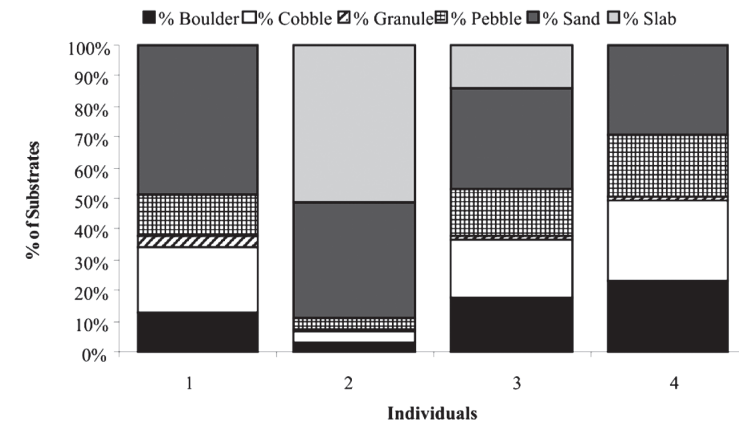

Figure 7. Aegla manuinflata. Occupation percentage of different types of substrate (sand, cobble, granule, slab, boulder and gravel) by four individuals (1, 2, 3 and 4) at natural environment. Animals monitored by radio-telemetry at a stream on Southern Brazil on February/2009.

days without any movement, or in almost total inactivity (Fig. 5), followed by re-establishment of locomotion.

\section{Circadian activity}

The four aeglids individuals exhibited higher displacement activity during the dark photophase. Although their activity was not restricted to the sunset period and night (Fig. 6), it was concentrated between 11:43 p.m. and 2:25 a.m. (Rayleigh Test) (Tab. 4, Fig. $6)$. There was a significant difference in the activity patterns between individuals 1 and 2 $\left(\chi^{2}=24.632 ; \mathrm{p}=8.81 \mathrm{E}-4\right)$ and 1 and $4\left(\chi^{2}=\right.$ 22.122; $\mathrm{p}=0.002)$.

\section{Space occupation}

The individual specificity regarding to the occupation of different kinds substrate was proved by Mantel test (SM1: $r=0.20$; $\mathrm{p}=0.0002$ ), but a pattern in the substrate occupation as a function of the photoperiod (day/night) was not observed (SM2: $\mathrm{r}=-0.005$; $\mathrm{p}=0.06$ ).

Among the four analyzed individuals, $\mathrm{n}^{\circ} 2$ exhibited a differentiated mode of occupation, using mainly slate as a substrate, whereas the other three used more often the sand substrate. It should also be noted that $\mathrm{n}^{\circ} 4$ used boulder substrates more often than the other individuals (Fig. 7).

\section{Discussion}

The present study is the first research employing the radio-telemetry technique that proved to be an efficient method for improving the biological knowledge and behavior of aeglids. These animals usually spend most 
of time under rocks and other substrates in rivers and streams making almost impossible to observe and follow these individuals. The results obtained in this study supply information about displacement circadian activity and substrate occupation patterns of $A$. manuinflata in their natural habitat. In spite of the use of only few individuals, radio-telemetry data were sufficient to reveal variability among then, as well as for the different activities of the same individual in the space and in the time, confirming the success of this technique in previous studies with other crustaceans (Clark et al., 1999; Gherardi et al., 2000; Lynch and Rochette, 2007).

Aegla manuinflata exhibited significant displacement rates. The knowledge of displacement and migration patterns of Aeglidae species is scanty. Lopez (1965) using tagging and recapturing methods between the months of July and December, reported that A. paulensis Schmitt, 1942 displaced approximately $300 \mathrm{~m}$ along a stream. This value is about three times of the average displacement of the present study (117.87 $\mathrm{m})$, but $A$. manuinflata could displace much more if the observation lasted six months as conducted by Lopez (1965). On the other hand, after one year of observations using the same technique and 32 records, Gherardi et al. (2000), verified that Procambarus clarkii crayfish showed an average movement of $44 \mathrm{~m}$ in Italy, which could be considered a minor displacement compared to the average displacement exhibited by $A$. manuinflata during the eight days of monitoring we conducted in southern Brazil. Barbaresi et al. (1997) recorded a maximum displacement of $22.5 \mathrm{~m}$ per day, when studying the fresh water crab Potamon fluviatile (Herbst, 1785) using radio-telemetry techniques. Finally, Robinson et al. (2000) calculated an average daily movement pattern of less than 5 meters when studying the crayfish Austrapotamobius pallipes; in addition, the authors also reported movements of more than $300 \mathrm{~m}$ in 10 days. These previous results related to daily movement are inferior to those obtained for A. manuinflata in the present study, which may be related to natural conditions such as the high mobility of aeglids or even to a higher motivation to move in search of different resources. The displacement degree was highly variable among individuals, both for daily displacement and for total (considering all days and periods of observation) displacement. The dispersion rate in the habitat could be related to a combination of different factors, including the occupation of shelters, which serve as an ephemeral home range (Gherardi et al., 1998, Robinson et al., 2000; Aquiloni et al., 2005), where some individuals remaining there for some time, whereas others choose to disperse.

Streams are dynamic systems and the distribution pattern of invertebrates that inhabit this environment may vary as a response to changes in stream flow velocity and temperature and biotic interactions. Small-scale movements in response to changes in flow velocity have been demonstrated for a number of macroinvertebrates that inhabit lotic environments (Lancaster, 1999). For many invertebrates living in streams, drift is an important means of transportation (Allan and Feifarek, 1989; Lancaster et al., 1996), but large vagile invertebrates are able to perform active movements, including traveling substantial distances against the flow (Robinson et al., 2000).

We found that displacement of $A$. manuinflata took place both downstream and upstream, being the latter were considerably greater. In other crustaceans that live in similar environments to aeglids', such as crayfishes, it has been shown that understanding the spatial and temporal patterns of their movements and activities is relevant to predicting their expansion and colonization capacity. Numerous studies with crayfish species have shown that radio-telemetry is a very effective technique to analyze the movement patterns of adults in river systems (Schütze et al., 1999; Bohl, 1999; Gherardi and Barbaresi, 2000; Robinson et al., 2000).

In the present study, specimens moved actively upstream, i.e., they were able to move against the stream flow. Upstream movement 
in rivers and sometimes on land has previously been reported for some crayfish species, such as Orconectes nais (Faxon, 1885) (Momot, 1966), P. leniusculus (Light, 2003) and P. clarkii (Kerby et al., 2005), which usually moved downstream. According to these authors, both stream flow velocity and height of obstacles can decrease or prevent the movement of crayfishes upstream. The aeglids are clearly able to move upstream which would allow then to invade or reoccupy areas upstream from which, in turn, they eventually could have been removed due to flooding (Light, 2003). Apparently, these animals prefer to move upstream where they find more oxygenated water, an important feature for aeglids.

Previous studies indicated that obstacles (natural and artificial barriers) such as waterfalls limit the movement of aquatic species in rivers negatively affecting their dispersion mechanisms (Utzinger et al., 1998; Benstead et al., 1999; Luttrell et al., 1999; Joy and Death, 2001; Kerby et al., 2005). However, A. manuinflata proved to be able to overcome barriers (waterfalls) of almost $1 \mathrm{~m}$ high, as previously reported for $A$. paulensis (Lopez, 1965). This information reinforces the concept of the capability of a habitat recolonization by aeglids, which have already been suggested by the fact that these animals tend to move upstream.

By means of radio monitoring one could verify that some individuals may become totally inactive and occupy the same area for a long period that can be few hours or more than a day, until they start moving actively again. These changes in movement activity did not follow a periodic pattern, and showed some variation for the same individual. A similar pattern has been reported for various crustacean species: A. pallipes (Gherardi et al., 1998), C. sapidus (Carr et al., 2004), Cancer pagurus Linnaeus, 1758 (Skajaa et al., 1998), P. leniusculus, (Bubb et al., 2004), P. fluviatile (Barbaresi et al., 1997), P. clarkii (Gherardi and Barbaresi, 2000; Gherardi et al., 2000; Aquiloni et al., 2005; Barbaresi et al., 2004; Barbaresi and Gherardi, 2006).

According to Skajaa et al. (1998) after being fed to satiation or in periods of low motivation to eat, C. pagurus remains inactive, probably to minimize the energetic cost of moving. This could be an explanation for the fluctuation between activity and inactivity periods in $A$. manuinflata. In addition, the preference to a specific area might indicate that such site serves as a "shelter", being associated with food supply and prevention of predation. Therefore, aeglids are only expected to move when there is an additional cost (competition, predation, scarce food) to remaining in the same area. In the present study, individuals that remained inactive for a long period of time were those who occupied areas with submerged vegetation. It is possible that these areas provided them an ideal supply of food and shelter, without any necessity in expending energy for displacement.

The movements of specimens of $A$. manuinflata were guided by nyctohemeral rhythms, and these animals were observed to have nocturnal habits, although they did not move exclusively during the night. In laboratory studies, Sokolowicz et al. (2007) reported nocturnal habits for $A$. longirostri Bond-Buckup and Buckup, I994, confirming this tendency to be more active in periods of low luminosity, both in their natural environment and in the laboratory.

Nocturnal habits have been broadly reported for decapod crustaceans (Atkinson and Naylor, 1976; Barbaresi et al., 1997; Gherardi et al., 2000; Barbaresi and Gherardi, 2001; Carr et al., 2004; Aquiloni et al., 2005; Jury et al., 2005; Golet et al., 2006; Sokolowicz et al., 2007). More activities during the night might be an adaptive response because it may allow these animals to escape from temperature extremes and to avoid possible predators that are visually orientated and therefore most active during the day (Barbaresi et al., 1997; Skajaa et al., 1998; Sokolowicz et al., 2007).

According to Atkinson and Naylor (1976), changes in light intensity during sunset and sunrise could have direct effects on activity of Norway lobster, Nephops norvegicus (Linnaeus, 1758). Moreover, light might also have an indirect effect in controlling the 
availability of food and predators. Concerning aeglids, the possibility of avoiding predators is probably one of the main reasons for their nocturnal habits, since they feed mostly on allochthonous plant matter (Bueno and Bond-Buckup, 2004; Castro-Souza and BondBuckup, 2004; Santos et al., 2008).

Aeglids exhibited specificity in the occupied substrate. However, this specificity did not occur due to circadian rhythms, such variation is a function of individuals $\left(\mathrm{n}^{\circ} 1,2\right.$, 3 and 4) independent of periods. Benvenuto et al. (2008) observed that the crayfish $A$. pallipes of different size classes occurred mainly in substrate of mud, gravel and pebbles, but adults preferred boulders. In addition, the occupation of a certain substrate by crayfish is independent from its availability but is related to the size of the crayfish with larger animals associated with larger substrates (grossly divided) (Benvenuto et al. 2008). Adequate substrates may offer shelter against predators (Naura and Robinson, 1998; Ilhéu et al., 2003, Barbaresi et al., 2007) and prevent drifting. Surprisingly, $A$. manuinflata occupied a finely divided substrate (sand). Actually, sandy substrates were associated with marginal and submerged vegetation, which could also serve as shelter and food source. This assumption is supported by the observation that most aeglids spent long time in sandy substrates, but further studies are desirable in order to find a pattern of occupation according to the substrate composition.

The result obtained in this study emphasizes the importance of preserving natural environments, aiming the conservation of aeglid species. According to Kerby et al. (2005), both velocity and high barriers reduce or even eliminate, the movement of the crayfish $P$. clarkii upstream the watershed. It is known that, Brazilian southern river systems are more fragmented by dams than those in other South American regions (Nilsson et al., 2005). The construction of big barriers, such as hydroelectric power plants, surely, may block the displacement of aeglids upstream and consequently the genetical exchange between populations will be permanently prevented.
In this study, the new technique allowed to answer three questions that had previously been raised: firstly, $A$. manuinflata was able to move actively along the stream, both downstream and upstream, including overcoming of obstacles; secondly, the studied aeglids are active mainly during the night, supporting previous observations made in laboratory, similar to many know decapod crustaceans; thirdly, in the studied area, considering the microhabitat diversity supplied by the sedimentary scales and the presence of vegetation over banks, the selectivity of the substrate was not generally associated with the sediment texture, but it was a clear individual response of each studied organism. The observations and results showed in the present study were obtained from aeglids monitored in their natural habitat resulting in a high degree of reliability of the biological and behavioral data collected from these crustaceans.

\section{Acknowledgments}

To Conselho Nacional de Desenvolvimento Científico e Tecnológico (CNPq) for a scholarship granted to LAP, and productivity fellowships granted to PBA and SS. We are special thankful to Ms. Alexandrina Cavichioli Brutt, Ms. Naide B. Peres and Mr. La-Hire Riss Peres (in. mem.) for hospitality during the field work; to Dra. Aline Quadros, Dra. Marcia Spies and Dr. Tiago Gomes dos Santos for helping us on the statistical analyses; to Idea Wild for donating the equipment, and to Dr. J. Antonio Baeza and anonymous reviewers for their criticism and suggestions on an early version of the manuscript. All experiments conducted in this study were in accordance with state and federal laws.

\section{References}

Allan, J.D. and Feifarek, B.P. 1989. Distances travelled by drifting mayfly nymphs: factors influencing return to substratum. Journal of 
the North American Benthological Society, 8(4): 322-330.

Aquiloni, L.; Ilhéu, M. and Gherardi, F. 2005. Habitat use and dispersal of the invasive crayfish Procambarus clarkii in ephemeral water bodies of Portugal. Marine and Freshwater Behavioral and Physiology, 38(4): 225-236.

Aréchiga, M. and Atkinson, R.J.A. 1975. The eye and some effects of light on locomotor activity in Nephrops norvegicus. Marine Biology, 32(1): 63-76.

Aréchiga, H. and Rodríguez-Sosa, L. 1997. Coupling of environmental and endogenous factors in the control of rhythmic behaviour in decapod crustaceans. Journal of the Marine Biological Association of the United Kingdom, 77(1): 17-29.

Aréchiga, H.; Fernández-Quiróz, F.; Fernández de Miguel, F. and Rodríguez-Sosa, L. 1993. The circadian system of crustaceans. Chronobiology International, 10(1): 1-19.

Arenas, J. 1976. La cordillera de la costa como refugio de la fauna dulcícola preglacial. Archivos de Biología y Medicina Experimentales, 10: 1-40.

Atkinson, R.J.A. and Naylor, E. 1976. An endogenous activity rhythm and the rhythmicity of catches of Nephops norvegicus (L). Journal of Experimental Marine Biology and Ecology, 25: 95-108.

Barbaresi, S. and Gherardi, F. 2001. Daily activity of the white-clawed crayfish, Austropotamobius pallipes (Lereboulett): a comparison between field and laboratory studies. Journal of Natural History, 35(12): 1861-1871.

Barbaresi, S. and Gherardi, F. 2006. Experimental evidence for homing in the red swamp crayfish, Procambarus clarkii. Bulletin Francais de la Peche et de la Pisciculture, 380-381: 1145-1154.

Barbaresi, S.; Gherardi, F. and Vannini, M. 1997. Movement patterns of river crabs (Decapoda, Potamoidea) in the field: predictable and unpredictable components. Journal of Zoology, 242(2): 247-259.

Barbaresi, S.; Santini, G.; Tricarico, E. and Gherardi, F. 2004. Ranging behaviour of the invasive crayfish, Procambarus clarkii
(Gerard). Journal of Natural History, 38(22): 2821-2832.

Barbaresi, S.; Cannicci, S.; Vannini, M. and Fratini, S. 2007. Environmental correlates of two macro-decapods distribution in Central Italy: Multi-dimensional ecological knowledge as a tool for conservation of endangered species. Biological Conservation, 136(1): 431-441.

Benstead, J.P.; March, J.G.; Pringle, C.M. and Scatena, F.N. 1999. Effects of a low-head dam and water abstraction on migratory tropical stream biota. EcologicalApplications, 9(2): 656-668.

Benvenuto, C.; Gherardi, F. and Ilhéu, M. 2008. Microhabitat use by the whiteclawed crayfish in a Tuscan stream. Journal of Natural History, 42(1-2): 21-33.

Bohl, E. 1999. Motion of individual noble crayfish Astacus astacus in different biological situations: in-situ studies using radio telemetry. Freshwater Crayfish, 12: 677-687.

Bubb, D.H.; Lucas, M.C. and Thom, T.J. 2002a. Winter movements and activity of signal crayfish Pacifastacus leniusculus in an upland river, determined by radio telemetry. Hydrobiologia, 483(1-3): 111-119.

Bubb, D.H.; Lucas, M.C.; Thom, T.J. and Rycroft, P. 2002. The potential use of PIT telemetry for identifying and tracking crayfish in their natural environment. Hydrobiologia, 483(1-3): 225-230.

Bubb, D.H.; Thom, T. J. and Lucas, M.C. 2004. Movement and dispersal of the invasive signal crayfish Pacifastacus leniusculus in upland rivers. Freshwater Biology, 49(3): 357-368.

Bueno, A.A.P. and Bond-Buckup, G. 2004. Natural diet of Aegla platensis Schmitt and Aegla ligulata Bond-Buckup \& Buckup (Crustacea, Decapoda, Anomura) from Brazil. Acta Limnológica Brasiliensia, 16(2): 115-127.

Bond-Buckup, G.; Buckup, L. and Araujo, P.B. 2003. Crustáceos, p. 73-83. In: Fontana, C. S.; Benke, G.A. and Reis, R.E. (org.), Livro Vermelho da fauna ameaçada de extinção no Rio Grande do Sul. 1 ed. Edipucrs, Porto Alegre. 
Carr, S.D.; Tankersley, R.A.; Hench, J.L.; Forward Jr., R.B. and Luettich Jr, R.A. 2004. Movement patterns and trajectories of ovigerous blue crabs Callinectes sapidus during the spawning migration. Estuarine, Coastal and Shelf Science, 60(4): 567-579.

Cassini, M.H.; Fasola, L.; Chehébar, C. and Macdonald, D.W. 2009. Scale-dependent analysis of an otter-crustacean system in Argentinean Patagonia. Naturwissenschaften, 96(5): 593-599.

Castro-Souza, T. and Bond-Buckup, G. 2004. O nicho trófico de duas espécies simpátricas de Aegla Leach (Crustacea, Aeglidae) no tributário da bacia hidrográfica do Rio Pelotas, Rio Grande do Sul, Brasil. Revista Brasileira de Zoologia, 21(4): 805-813.

Cesaroni, D.; Matarazzo, P.; Allegrucci, G. and Sbordoni, V. 1997. Comparing patterns of geographic variation in cave crickets by combining geostatistic methods and Mantel tests. Journal of Biogeography, 24(4): 419-431.

Clark, M.E.; Wolcott, T.G.; Wolcott, D.L. and Hines, A.H. 1999. Foraging and agonistic activity co-occur in free-ranging blue crabs (Callinectes sapidus): observation of animals by ultrasonic telemetry. Journal of Experimental Marine Biology and Ecology, 233(1): 143-160.

Cohen, D. and Levin, S.A. 1991. Dispersal in patchy environments: the effects of temporal and spatial structure. Theoretical Population Biology, 39(1): 63-99.

Gherardi, F. and Barbaresi, S. 2000. Invasive crayfish: activity patterns of Procambarus clarkii in the rice fields of the Lower Guadalquivir. Archiv für Hydrobiologie, 150(1): 153-168.

Gherardi, F; Barbaresi, S. and Villanelli, F. 1998. Movement patterns in the whiteclawed crayfish Austropotamobius pallipes, in a Tuscan stream. Journal of Freshwater Ecology, 13(4): 413-424.

Gherardi, F.; Barbaresi, S. and Salvi, G. 2000. Spatial and temporal patterns in the movement of Procambarus clarkii, an invasive crayfish. Aquatic Sciences, 62(2): 179-193.

Golet, W.J.; Darren, A.S.; Cooper, A.B. and
Watson III, W.H. 2006. Daily pattern of locomotion expressed by American lobsters (Homarus americanus) in their natural habitat. Journal of Crustacean Biology, 26(4): 610-620.

Guerra-Castro, E.; Carmona-Suárez, C.A. and Conde, J.E. 2007. Activity patterns and zonation of the swimming crabs Arenaeus cribrarius and Callinectes ornatus. Journal of Crustacean Biology, 27(1): 49-58.

González-Gurriarán, E.; Freire, J. and Bernárdez, C. 2002. Migratory patterns of female spider crabs Maja squinado detected using electronic tags and telemetry. Journal of Crustacean Biology, 22(1): 91-97.

Hammer, Ø.; Harper, D.A.T. and Ryan, P.D. 2001. PAST: Paleontological Statistics Software Package for Education and Data Analysis. Palaeontologia Electronica, 4: http://palaeo-electronica.org/2001_1/past/ issue1_01.htm

Hedin, J. and Ranius, T. 2002. Using radio telemetry to study dispersal of the beetle Osmoderma eremite, an inhabitant of tree hollows. Computers and Electronics in Agriculture, 35: 171-180.

Ilhéu, M.; Acquistapace, P.; Benvenuto, C. and Gherardi, F. 2003. Shelter use of the redswamp crayfish (Procambarus clarkii) in a dry-season stream of South Portugal. Archiv fur Hydrobiologie, 157(4): 535-546.

Jørgensen, T.; Løkkeborg, S.; Fernö, A. and Hufthammer, M. 2007. Walking speed and area utilization of red king crab (Paralithodes camtschaticus) introduced to the Barents Sea coastal ecosystem. Hydrobiologia, 582(1): 17-24.

Joy, M.K. and Death, R.G. 2001. Control of freshwater fish and crayfish community structure in Taranaki, New Zealand: dams, diadromy or habitat structure? Freshwater Biology, 46(3): 417-429.

Jury, S.H.; Chabot, C.C. and Watson III, W.H. 2005. Daily and circadian rhythms of locomotor activity in the American lobster (Homarus americanus). Journal of Experimental Marine Biology and Ecology, 318(1): 61-70.

Karnofsky, E.B.; Atema, J. and Elgin, R.H. 1989. Natural dynamics of population 
structure and habitat use of the lobster, Homarus americanus in a shallow cove. Biological Bulletin, 176(3): 247-256.

Kerby, J.L.; Riley, S.P.D.; Kats, L.B. and Wilson, P. 2005. Barriers and flow as limiting factors in the spread of an invasive crayfish (Procambarus clarkii) in southern California streams. Biological Conservation, 126: 402-409.

Kokko, H. and López-Sepulcre, A. 2006. From individual dispersal to species ranges: Perspectives for a changing world. Science, 313(5788): 789-791.

Kovach, W.L. 1994. Oriana for Windows, version 1.03. Kovach Computer Services, Pentraeth, Wales, U.K.

Lancaster, J. 1999. Small-scale movements of lotic macroinvertebrates with variations in flow. Freshwater Biology, 41(3): 605-619.

Lancaster, J.; Hildrew, A.G. and Gjerlov, C. 1996. Invertebrate drift and longitudinal transport process in streams. Canadian Journal of Fisheries and Aquatic Sciences, 53(3): 572-582.

Levine, S.A.; Cohen, D. and Hastings, A. 1984. Dispersal strategies in patchy environments. Theoretical Population Biology, 26: 165-191.

Light, T. 2003. Success and failure in a lotic crayfish invasion: the roles of hydrologic variability and habitat alteration. Freshwater Biology, 48(10): 1886-1897.

Lopez, M. T. 1965. Estudios biologicos en Aegla odebrechtti paulensis, Schmitt (Crustacea, Decapoda, Anomura). Boletim de Zoologia da Faculdade de Filosofia Ciências e Letras de São Paulo, 25: 301-314.

Luttrell, G.R.; Echelle, A.A.; Fisher, W.L. and Eisenhour, D.J. 1999. Declining status of two species of the Macrhybopsis aestivalis complex (Teleostei: Cyprinidae) in the Arkansas River Basin and related effects of reservoirs as barriers to dispersal. Copeia, 1999(4): 981-989.

Lynch, B.R. and Rochette, R. 2007. Circatidal rhythm of free-roaming sub-tidal green crabs, Carcinus maenas, revealed by radioacoustic positional telemetry. Crustaceana, 80(3): 345-355.

Magris, R.A.; Bond-Buckup, G.; Magalhães, C.; Mantelatto, F.L.; Reid, J.W.; Elmoor-
Loureiro, L.M.A.; Coelho, P.B.; Santana, W.; Buckup, L., Rocha, S.S.; Bueno, S.L.S.; Pinheiro, M.A.A.; D'Incao, F.; Ivo, C.T.C.; Neto, J.D.; Rodrigues, E.S.; Araujo, P.B.; Boos Júnior, H.; Duarte, L.F.A. 2010. Quantification of extinction risk for crustacean species: an overview of the National Red Listing process in Brazil. Nauplius, 18(2): 129-135.

Manly, B.F.J. 1990. Multivariate statistical methods: a primer, 159 pp. Chapman and Hall, London.

Manly, B.F.G. 2000. Multivariate statistical methods - a primer. $2^{\text {nd }}$ ed. Boca Raton (FL): Chapman and Hall, London.

McLaughlin, P.A.; Lemaitre, R. and Crandall, K.A. 2010. Annotated checklist of anomuran decapod crustaceans of the world (exclusive of the Kiwaoidea and families Chirostylidae and Galatheidae of the Galatheoidea) part III - Aegloidea. The Raffles Bulletin of Zoology, 23: 131-137.

Meyer-Rochow, V.B. 1994. Light-induced damage to photoreceptors of spiny lobsters and other crustaceans. Crustaceana, 67(1): 95-109.

Momot, W.T. 1966. Upstream movement of crayfish in an intermittent Oklahoma stream. American Midland Naturalist, 75(1): 150-159.

Morales J.M. and Ellner, S.P. 2002. Scaling up animal movements in heterogeneous landscapes: The importance of behavior. Ecology, 83(8): 2240-2247.

Naura, M. and Robinson, M. 1998. Principles of using river habitat survey to predict the distribution of aquatic species: an example applied to the native white-clawed crayfish Austrapotamobius pallipes. Aquatic Conservation, 8: 515-527.

Nilsson, C.; Reidy, C.A.; Dynesius, M. and Revenga, C. 2005. Fragmentation and flow regulation of the world's large river systems. Science, 308(5720): 405-408.

Palmer, J.D. 1995. The biological rhythms and clocks of intertidal animals. Oxford University Press, New York.

Patterson, T.A.; Thomas, L.; Wilcox, C.; Ovaskainen, O. and Matthiopoulos, J. 2008. State-space models of individual 
animal movement. Trends in Ecology and Evolution, 23(2): 87-94.

Pérez-Losada, M.; Jara, C.G.; Bond-Buckup, G. and Crandall, K.A. 2002. Conservation phylogenetics of Chilean freshwater crabs Aegla (Anomura: Aeglidae): assigning priorities for aquatic habitat protection. Biological Conservation, 150: 345-353.

Robinson, C.A.; Thom, T.J. and Lucas, M.C. 2000. Ranging behaviour of a large freshwater invertebrate, the whiteclawed crayfish Austropotamobius pallipes. Freshwater Biology, 44(3): 509-521.

Rohlf, F.J. 2000. NTSYS 2.1: Numerical Taxonomy and Multivariate Analysis System. Exeter Software, New York.

Santos, S.; Ayres-Peres, L.; Cardoso, R.C.F. and Sokolowicz, C.C. 2008. Natural diet of the freshwater anomuran Aegla longirostri (Crustacea, Anomura, Aeglidae). Journal of Natural History, 42(13-14): 1027-1037.

Santos, S.; Bond-Buckup, G.; Pérez-Losada, M.; Bartholomei-Santos, M.L. and Buckup, L. 2009. Aegla manuinflata, a new species of freshwater anomuran (Decapoda: Anomura: Aeglidae) from Brazil, determined by morphological and molecular characters. Zootaxa, 2088: 3140.

Schütze, S.; Stein, H. and Born, O. 1999. Radio telemetry observations on migration and activity patterns of restocked noble crayfish Astacus astacus (L.) in the small river Sempt, North-East of Munich, Germany. Freshwater Crayfish, 12: 688-695.

Skajaa, K.; Ferno, A.; Lokkeborg, S. and Haugland, E.K. 1998. Basic movement pattern and chemo-oriented search towards baited pots in the edible crab (Cancer pagurus L.). Hydrobiologia, 371/372: 143153.

Smith, I.P.; Collins, K.J. and Jensen, A.C. 1998. Movement and activity patterns of the European lobster, Homarus gammarus, revealed by electromagnetic telemetry. Marine Biology, 132(4): 611-623.

Smouse, P.E.; Long, J.C. and Sokal, R.R. 1986. Multiple regression and correlation extensions of the Mantel test of matrix correspondence. Systematic Zoology, 35(4):
627-632.

Sokal, R.R. 1979. Testing statistical significance of geographic variation patterns. Systematic Zoology, 28(2): 227-232.

Sokolowicz, C.C.; Ayres-Peres, L. and Santos, S. 2007. Atividade nictimeral e tempo de digestão de Aegla longirostri (Crustacea, Decapoda, Anomura). Iheringia, Série Zoologia, 97(3): 235-238.

Southwood, T.R.E. 1977. Habitat, the templet for ecological strategies? Journal of Animal Ecology, 46: 337-365.

Steinberg, E.K. and Kareiva, P.M. 1997. Challenges and opportunities for empirical evaluation of "spatial theory", p. 368, In: Tilman, D and Kareiva, P.M. (eds), Spatial ecology: The role of space in population dynamics and interspecific interactions. Princeton University Press.

Sutherland, W.J. 1996. From individual behaviour to population ecology. Oxford, University Press, UK.

Turchin, P. 1998 Quantitative analysis of movement: Measuring and modeling population redistribution in animals and plants. Sinauer Associates, Massachusetts.

Turner, H.V.; Wolcott, D.L.; Wolcott, T.G. and Hines, A.H. 2003. Post-mating behavior, intramolt growth, and onset of migration to Chesapeake Bay spawning grounds by adult female blue crabs, Callinectes sapidus Rathbun. Journal of Experimental Marine Biology and Ecology, 295(1): 107-130.

Utzinger, J.; Roth, C. and Peter, A. 1998. Effects of environmental parameters on the distribution of bullhead Cottus gobio with particular consideration of the effects of barriers. Journal of Applied Ecology, 35(6): 882-892.

Watson III, W.H.; Vetrovs, A. and Howell, W.H. 1999. Lobster movements in an estuary. Marine Biology, 134(1): 65-75.

Wolcott, T.G. 1995. New options in physiological and behavioral ecology through multichannel telemetry. Journal of Experimental Marine Biology and Ecology, 193(1-2): 257-275. 